\title{
OBITUARY
}

\section{Thesigamoney Reddy}

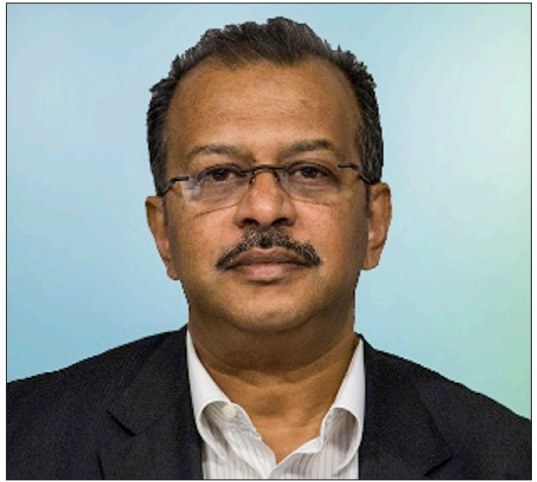

Thesigamoney Reddy was born in 1959 in Dundee to Mogambary and Vijyapushni Reddy, the eldest of four siblings. The family later moved to Mobeni Heights, where he went to school and excelled academically as well as in athletics, running the 400 metres at provincial level. The family then relocated to Dublin, Ireland. He attended the prestigious Wesley College in Dublin, where he attained outstanding results, allowing him to pursue his childhood dream of studying medicine at the Royal College of Surgeons.

After completing medical school in Ireland, he returned to Durban where he met his wife, Dr Mohinie Moodley, and raised his three children, Kavithan, Nimalan and Santhuri. He furthered his studies and became a Fellow of the College of Paediatricians. During this time he travelled to Canada, where he had the opportunity to train in neonatology, returning to Durban to share his skills with the specialist community.

Dr Reddy was highly respected as a paediatrician and intensivist. In addition he was ever willing to help with patients. He never could say no to a colleague or to a patient. He worked long and arduous hours, doing a labour of love. He served on the boards of the Sherwood Assessment Centre, the Paediatric Management Group and the KZN Specialist Network and as a director of Joint Medical Holdings. The KZN Specialist Network was particularly close to his heart, and he served it as an executive member for the last 17 years of his life. He built up a special relationship with many of the funders and knew many of them personally. His calmness, keen perception of issues at stake, and sound, well-reasoned perspective were welcomed by all. He will be remembered for his passion, work ethic and commitment.

To Dr Reddy, family meant everything. In spite of all his commitments he always had time for his family. They accompanied him on most of his holidays, and he was actively engaged in their pursuits.
His kindness extended to animals, in particular dogs, a love for which he shared with his family. He had an in-depth knowledge of lineage and breeding lines which led him to pursue his passion for breeding and importing rottweilers. $\mathrm{He}$ travelled extensively, having the good fortune of sharing this interest with his wife and children. His wide range of interests included cooking, listening to classical music, and a love for history, golf and photography. He also had a deep interest in Saivism.

Unfortunately, he was struck by two rare malignancies. He was determined to fight this illness and did so to the very end, doing extensive research and making contact with experts across the globe. His courage and determination to continue fighting cancer two times over are remarkable.

Dr Reddy gave selflessly to his family, his patients and those in need. We ask that all who knew him keep his memory in your hearts and keep his legacy going. Inspire others to do good for one another, and help your fellow man.

\section{Lionel Kunnie}

Durban, South Africa

lionel@ispace.co.za 